\title{
Effect of the Political Risk on Capital Asset Valuation in Financial Markets: The Case of Turkey ${ }^{1}$
}

\author{
Cengiz Toraman ${ }^{\mathrm{a}}$
}

\author{
Merve Tuncay ${ }^{b}$
}

\begin{abstract}
Recent political events and the subsequent movements in financial markets both in the developing and the developed countries raise the instincts regarding the interaction of political risks and financial markets and increase the importance of understanding the behavior of financial markets against political risks. Therefore the purpose of this study is to explain the impact of political risks on the returns of securities traded on capital markets in Turkey in the framework of Capital Asset Pricing Model (CAPM). The relation between the monthly returns of 47 companies' assets being traded on Borsa Istanbul and the political risks in Turkey between the years of 1997 and 2013 is examined in the study. Results of the analysis held by two-step regression method represent that there exists a positive and linear relation between beta and expected return. On the other hand, it is found that 4 out of 12 political risk factors, in other words internal conflict, external conflict, government stability and military in politics have a significant impact on expected return. Contrary to the other three risk factors, only the risk of government stability is found to be positively affecting asset returns.
\end{abstract}

Keywords: Political Risk, Borsa Istanbul, Capital Asset Pricing Model, Financial Markets, E-views

JEL Classification: C31, C32, E44, G11, G12, P48

\section{Introduction}

Today it is believed that not only economic factors but also political factors have a decisive role on performance in the financial markets. Even, it is remarkable that financial and political factors are in constant interaction with each other. Integration of financial markets also reveals that political risks should also be taken into consideration more than ever. Because, capital flows, getting beyond the limits as a result of liberalization and playing an important role in economic stability, acts hypersensitively in the form of rapid retreat especially in the event of any political instability. Hence such an insecure situation may lead to consequences up to a stock market crash. As a matter of fact, ongoing tensions between Ukraine and Russia since the beginning of 2014 and the stock market fluctuations called to mind the existence of such interactions. Turkey has also had similar experiences in which a noneconomic event in or out of Turkey followed by fluctuations in the financial markets. Turkish Stock Exchange bore various fluctuations following the events like the Gulf War on August 2, 1990, demise of Turkish president on April 19, 1993, post-modern coup process on February 28, 1997, earthquake of Marmara on August 17, 1999, the argument between the Turkish president and the prime minister on February 19, 2001, attacks against the twin towers of the World

aProf., PhD., Izmir Democracy University, Faculty of Economics and Administrative Sciences, Izmir, Turkiye, cengiztoraman@gmail.com

${ }^{b}$ Asst. Prof., PhD., Cumhuriyet University, Faculty of Economics and Administrative Sciences, Department of Banking and Finance, Sivas, Turkiye, mtuncay@cumhuriyet.edu.tr 
Trade Center on September 11, 2001, bomb attacks at the HSBC Bank Headquarter and the British Embassy on November 20, 2003 and so on. All such events and subsequent fluctuations in the stock market exchange increased the instincts related to the vulnerability of financial markets against political risks regardless of whether they are in or out of the country and under or out of the government's control.

Beginning of political risks being considered in the economic researches dates back to the early 1980s. Expropriation policies and therefore decisions to have rights over assets and incomes of investors becoming widespread among developing countries since the $1970 \mathrm{~s}$ triggered studies based on the determinants and results of political risks (Harms, 2000: 95).

Political risk basically means the possibility of a threat from a government to change the rules of the game after the investment made. In the worst case, a government may expropriate all the assets a company has without any compensation. Or they may demand the company to keep all the profits it makes in the host country (Brealey et al., 2001:616). In other words, political risk includes the possibility of any negative change in the economy caused by the political agents (Keles, 2007: 55).

According to Loikas (2003), the political risk arises from the uncertainties in the relations of political, social and economic environment. Hence, political risk includes not only the decisions of governments that may affect the economy but also the political interferences caused by non-governmental agents. Accordingly, fall of a government by force, organization of assassinations and political rallies also compose political risk (Toptas, 1996: 137-138).

"To be the risk arising from political events and causing companies' assets or profitability to decrease" is asserted as a prominent feature of political risk (Finnerty, 2011: 80). It is said the source of this risk can be not only government policies and the changes in the regulatory environment but also events emerging beyond the control of governments such as wars, terrorism or military coups and this risk can affect both developed and the developing countries (Ramady, 2014: 55). Harms (2008) expresses that the countries comprise nonhomogenous individuals and groups and therefore conflicting attitudes regarding investments to the country should not be ignored. Parliamentary groups, ruling or opposing parties, lobbies and sects based on religious, ethnic or lingual separation are seen among formations that could lead to political risk in a country (Keles, 2007: 51).

According to the expressions above, we can describe political risk as "the possibility of host country, other countries, international institutions and nongovernmental organizations having effect on a company's national or international income, assets and investments by their political decisions and actions". Because as it can be seen, political risk arises from not only governmental issues but also the other political events out of government's control.

World Bank states that political risks arise from the factors like; transfer and convertibility restrictions, expropriation, breach of contract, non-honoring of sovereign financial obligations, terrorism, war, civil disturbance and other adverse regulatory changes. (World Bank Group, 2011: 21). According to Ramady (2014), responsibility of government in order to manage political risk is to fight against complex political and socioeconomic challenges and also counterbalance security with freedom, economic growth with social justice and private sector investments with public sector safety nets. He gives the debates of Arab Spring starting in Tunisia in 2011 as an example. Because countries having Arab Spring experience during this period faced not only political but also social and economic turmoil (Ramady, 2014: 3).

Since public sector needs to borrow debt in order to cover budget deficit or issue stocks of the commercial enterprises by transforming them into companies and those in the private sector willing to find new partners or debt through short and long term debt securities, both public and private sector come together in the securities market (Apak and Demirel, 2013: 30). Therefore, governments have the capability of influencing the functioning of financial markets using various debt management policies. Thus, policy changes have impact especially on stock markets as an increase in volatility and an increase in correlation between risk premiums and stocks as well. However, reaction of prices in the financial markets will be weak 
in the case of more predictable changes (Pastor and Veronesi, 2012: 1219-1220). Therefore the point which investors would focus on against political risk is the magnitude of unexpected impact caused by this risk.

Studying the literature on the interaction of political risks and the financial markets, it is found that especially the effects of democratization process were measured while the other components of political risks were not examined much. Even it is seen that there are not many studies regarding the effects of political variables on financial variables and also the assessment of the existing findings seems to be far from being evident. Hence this is the source of inspiration for this study to examine the role of political risks on asset returns in financial markets.

According to Henderson and Rodriguez (2008), it is reasonable to expect political risks to influence the returns in financial markets. Because the political structure of a country impacts directly or indirectly the way firms operate. By definition, political change effects the performance and thus the returns of companies' in financial markets. Likewise, some investors may prefer to invest in those countries having high political risks in the expectation of high returns (Henderson and Rodriguez, 2008: 4).

Another example regarding the interaction of political risks and the financial markets can be addressed through the issue of central banks and government decisions. For instance, management of a central bank in accordance with the government decisions may affect its capability to access various credit facilities easily. Because a central bank's ability to act independently is taken into account while assessing the country's credibility (Yasar, 2010: 26).

The purpose of this study is to reveal that political risk factors are also determinative on the valuation of assets in the capital markets together with the degree and direction of this impact through analyzing the returns of stocks being traded on Borsa Istanbul (BIST). The study handles the effect of political risks on asset returns within the framework of the Capital Asset Pricing Model (CAPM). One of the fundamentals of financial management is the idea that the more the risk being undertaken, the more the gain being expected. From this point of view, there are several methods developed in the literature in order to calculate the expected (average) returns of assets. Of all these methods, although it is still being criticized from some aspects, CAPM stands as one of the most preferred asset pricing models because of its easiness to apply.

The research is developed on the question whether stock returns can be explained by any political risk variables other than beta. Within this context, the effect of political risks on the capital markets in Turkey is studied by the econometric analysis of the data obtained from BIST and International Country Risk Guide (ICRG). For this purpose, monthly return percentages on Dollar basis of 47 companies being traded on BIST and included in BIST100 index between the years of 1997 and 2013 and also 12 political risk variables are utilized within the scope of the analysis.

\section{Literature Review}

Considering the studies examining the relationship between financial markets and political risks, it is seen that this effect has been handled by the panel data obtained especially from emerging markets (Mei, 1999; Perotti and van Oijen, 2001; Bilson, Brailsford and Hooper, 2002; Girard and Omran, 2007; Yartey, 2008; Henderson and Rodriguez, 2008; Dutta, 2009; Lehkonen and Heimonen 2015; Ghosh, 2016). Additionally, Dimic, Orlov, and Piljak (2015), analyze the effect of political risk on stock markets in the context of emerging, frontier and developed stock markets classification by panel data. Study finds that despite political risk affects all type of markets, individual effect of risk components differ according to the market category. However there are studies dealing with this issue on the basis of only one country as well (He, 1999; Kim and Mei, 2001; Yaprakli and Gungor, 2007; Sanlisoy and Kok, 2010; Suleman, 2012; Abdulqadir and Yaroson, 2013; Gul, Khan, Saif and Ur, 2013; Ada, Bolak, and Suer, 2013). Among the studies analyzing the effect of political risk on emerging markets, studies such as Bilson, Brailsford, and Hooper, (2002), Girard and Omran (2007) and Dutta (2009) can be seen utilizing CAPM as the method of the analysis. On the other hand, Atilgan, Demirtas, and Erdogan (2015) prefer Arbitrage Pricing Theory (APT) in order to investigate the relationship between macroeconomic factors and stock returns. They conduct a two-step analysis in which they estimate factor betas at the first step and then use this data at the second step as to measure the sensitivity of stock returns 
to factor betas. According to the findings, there is a significant and negative relationship between interest rates and stock returns.

Among these studies, Mei (1999), Keles (2007), Girard and Omran (2007), Yartey(2008), Dutta(2009), Sanlisoy and Kok (2010), Cam (2014), Kaya, Gungor and Ozcomak (2014), Dimic, Orlov and Piljak (2015), Erkocak and Cam (2015), Kara and Karabiyik (2015), Lehkonen and Heimonen (2015) prefer packet data published by institutions like ICB (International Crisis Behavior), ICRG or IFC; while Yaprakli and Gungor (2007), Bekaert, Harvey, Lundblad and Siegel (2012) prefer political risk premiums and finally He (1999), Kim and Mei(2001), Suleman (2012), Abdul-Qadir and Yaroson (2013), Gul et al. (2013) and Ada et al. (2013) take political events and news in the form of dummy variable as the indicator of political risk.

All these studies depict a significant relation among political risks and financial markets. On the other hand, Suleman (2012), despite finding out a significant relation among political news and stock returns and market volatility, indicates that oil and gas, finance sector and health sector are not affected by such news. Of all the political risk components, factors like corruption (Girard and Omran, 2007; Abdul-Qadir and Yaroson, 2013), terrorism (Gul et al., 2013), political (in)stability (Kim and Mei, 2001; Keleş, 2007; Girard and Omran, 2007; Henderson and Rodriguez, 2008; Sanlisoy and Kok, 2010), democratic accountability (Girard and Omran, 2007), socio-economic conditions (Girard and Omran, 2007), political elections or the regime (Mei, 1999; Dutta, 2009; Ada et al., 2013; Lehkonen and Heimonen, 2015), external conflict (Girard and Omran, 2007), bureaucracy quality (Yartey, 2008), law and order (Yartey, 2008) are found to be effective. Alternatively, Ghosh (2016) investigates the interaction between political and financial components in the context of banking sector. The research in which the effect of Arab Spring experiment on the risk and returns of the Middle East and North Africa (MENA) region banks is analyzed by panel data obtained from 12 MENA countries for the period of 2000-2012 concludes that Arab Spring lowered bank profitability while increasing bank risk. It is also found that there is not a differential effect on the Islamic Banks in terms of performance and stability. Similarly, Chau, Deesomsak, and Wang (2014) investigate the effect of political factors on financial markets by the data of MENA countries during Arab Spring. However, the study aims to compare the reactions of conventional and Islamic stock market indices against political uncertainty caused by the civil uprisings through multivariate GARCH model. According to the findings, political uncertainty affects financial volatility and Islamic indices react more than the conventional indices.

Investigating the studies specific to Turkey it is seen that IMKB100 (BIST100) index is chosen as the representative of the market (Keles, 2007; Yaprakli and Gungor, 2007; Ada et al., 2013; Kaya et al., 2014; Kara and Karabiyik, 2015 ) and only the negative or volatility effect of political risk on financial markets is set forth. However, it is seen there is no further explanation on which political risk factor or to what degree they are effective on financial markets. While Yaprakli and Gungor (2007) determines that there is a long-term relation between political risk premiums and IMKB100 index, Ada et al. (2013) find significant deviations from expected returns in stock markets during electoral periods. Kaya et al. (2014) also find a long run relationship between political risk and stock prices and a causality from political risk to stock prices by conducting regression, Granger Causality and Johansen Juselius Cointegration Analyses for the periods of 1998-2012. It is also found that political risk affects stock prices in a negative direction. Cam(2014) conclude that political risk effect firm value in a study investigating the interaction of financial markets and total political risk by panel data analysis for the period of 2000 and 2009. Erkocak and Cam (2015) found that besides economic risk premium and country risk premium, political risk premium also negatively affect stock prices and return on equity in the BIST for the period of 2003 and 3013. Kara and Karabiyik (2015) also supported previous research by determining that there exists a long and short run relationship between the stock prices and economic, financial, political and country risks and stock prices are negatively affected from these risk premiums for the period of 1999 and 2013. 


\section{Materials and Modeling}

Estimation of the expected return and calculation of its risk have always been among the concerns of both the academicians and the investors seeking for the best investment alternative. The aim of all these efforts is to better determine how stocks will act in the future through examining historical performances in order to compose a portfolio that will maximize the expected or estimated returns of investors.

Unlike aforementioned studies, this research aims to reveal whether expected returns of stocks are sensitive to political risks besides the changes they undergo in response to the volatilities in the market. As also argued by Bekaert et al. (2012), despite the fact that political risk may reflect systematic risk to a degree, it is actually a diversifiable risk especially for global investors since most of the political risks arise from country-specific conditions. Hence, the main purpose of this study is to indicate that political risk factors have also a determining role in Turkish capital markets along with the degree and direction of this effect by using returns of stocks traded on BIST in today's integrating financial markets world. When we consider the ambiguity of political risk and the heterogeneity of the events causing political risk (Keles, 2007: 178), it is reasonable to prefer a model having strong theoretical basis such as CAPM in order to explain the political risk factors affecting capital markets by using systematic risk as a benchmark despite the perfectionist assumptions of CAPM. Likewise, since the market portfolio is impossible to constitute, in practice indices like BIST100 (for Borsa Istanbul) are preferred as a proxy. Therefore it is far important to interpret the findings properly rather than conducting the analysis (Keles, 2007:178; Karan, 2013: 210-221). According to Ferson and Locke (1998), what is important from the point of practice is to better understand whether a model leads to systematically poor decisions or not rather than questioning the CAPM as a wrong or right one when we consider that all the models can be seen wrong to a degree as they are all stylized versions of the real world.

Since it is assumed from the previous research that political risks are also effective on capital markets a priori, the research is conducted within the framework of political risk subcomponents and stock returns. Accordingly, the analysis is carried out by CAPM presented by William Sharpe in 1964 which is now one of the most widely referred methods in the finance literature in order to explain security returns.

The model mainly uses only one risk factor named "market risk" or "systematic risk". The market risk here stands for the risk of holding a portfolio named "market portfolio" that comprises all the securities in the market (Aydin, 2008: 5).

On the basis of the model which is enabling a framework for the measurement of the systematic risk is that the market presents two types of prices to the investors (Sharpe, 1964: 425). In other words, expected return demanded by the investors depends on two factors arising from the return of the time value of money (risk-free rate) and also the risk premium based on beta and market risk premium (additional expected return for each unit of risk borne) (Brealey, Myers and Marcus, 2001: 416).

The logic of risk-free rate comes from the assumption that there are risk-free borrowing/lending opportunities in the market and all the consumers can borrow/lend as much as they wish at the rate aforementioned. The existence of this rate in the model helps to determine the efficient portfolio set among other investment alternatives easily (Fama and Miller, 1971: 44-45). This rate in the CAPM stands for the return of the asset which is assumed to have no risk of insolvency in the market. In practice, it is important to choose an appropriate asset representing the risk-free rate in order evaluation to be reasonable. Treasury bills and government bonds are preferred as suitable investment instruments for short term and long term estimations respectively (Grabowski, 2010: 1-2).

The model developed by Sharpe, Lintner, and Mossin can demonstrate that expected return of an asset, say $i$, is directly proportional to the market risk premium at the state of equilibrium (Fama and French, 2004: 29):

$$
E\left(R_{i}\right)=R_{f}+\beta_{i}\left[E\left(R_{M}\right)-R_{f}\right], \quad i=1, \ldots \ldots \ldots, n .
$$


Formula (1) depicts a consistent look with the investor behaviors presented in portfolio theory. Here, $\left[E\left(R_{M}\right)-R_{f}\right]$ represents the market risk premium. $R_{f}$ stands for the risk-free rate at which all the investors are assumed to borrow/lend as much as they wish (Fama and Miller, 1971: 288).

Market beta $\left(B_{i}\right)$ of the stock in the equation (1) is obtained by the covariance of stock $i$ and market portfolio divided by the variance of market portfolio (Fama and French, 2004: 28):

$$
\beta_{i}=\frac{\operatorname{cov}\left(R_{i}, R_{M}\right)}{\sigma^{2}\left(R_{M}\right)}
$$

CAPM reveals the following thought by this formula; "An asset should be priced as to yield a higher return, not because of the higher risk it has alone, but also because of its higher systematic risk" (Mishkin and Stanley, 2005: W-16).

On the point of investigating if political risk factors have an effect on stock returns within the framework of CAPM, dollar-based monthly average returns of 47 companies traded on BIST between the periods of 1997: January and 2013: June and BIST100 index, as the proxy of market return, are employed. The reasons for choosing the companies listed in Table 1 are as follows:

- Companies are chosen among publicly traded companies in order to obtain regular and accessible data,

- Companies composing BIST100 index continuously during the analysis period are included,

- Instead of focusing on one sector only, companies are chosen from as many sectors as possible, in order to generalize the findings for the Turkish stock market as a whole and finally,

- Holding the analysis period as long as possible so as to increase the variety and amount of political risk factors that the markets are thought to be exposed to in order to make longer term and realistic evaluations.

Therefore we tried to have the optimum data that will enable us to keep the sample as large as possible in terms of both the number of companies and the analysis period.

Table 1. List of Companies Included in the Analysis

\begin{tabular}{|c|c|c|c|c|c|}
\hline No & Code & Name of the Company & No & Code & Name of the Company \\
\hline 1 & AKBNK & Akbank & 25 & IHEVA & Ihlas Ev Aletleri \\
\hline 2 & AKCNS & Akcansa & 26 & IHLAS & Ihlas Holding \\
\hline 3 & AKSA & Aksa & 27 & ISCTR & İs Bankasi \\
\hline 4 & ALARK & Alarko Holding & 28 & IZMDC & Izmir Demir Celik \\
\hline 5 & ALGYO & Alarko GMYO & 29 & KARTN & Kartonsan \\
\hline 6 & ANACM & Anadolu Cam & 30 & $\mathrm{KCHOL}$ & Koc Holding \\
\hline 7 & ARCLK & Arcelik & 31 & KONYA & Konya Cimento \\
\hline 8 & ASELS & Aselsan & 32 & MUTLU & Mutlu Aku \\
\hline 9 & AYGAZ & Aygaz & 33 & NETAS & Netas Telekom. \\
\hline 10 & BAGFS & Bagfas & 34 & NTTUR & Net Turizm \\
\hline 11 & BRISA & Brisa & 35 & OTKAR & Otokar \\
\hline 12 & BRSAN & Borusan Mannesmann & 36 & PETKM & Petkim \\
\hline 13 & CIMSA & Cimsa & 37 & PTOFS & OMV Petrol Ofisi \\
\hline 14 & CLEBI & Celebi & 38 & SASA & Sasa Polyester \\
\hline 15 & $\mathrm{DOHOL}$ & Dogan Holding & 39 & SISE & Sise Cam \\
\hline 16 & ECILC & Eczacibasi llac & 40 & TEKST & Tekstilbank \\
\hline 17 & ECZYT & Eczacibasi Yatirim & 41 & THYAO & Turk Hava Yollari \\
\hline 18 & EREGL & Eregli Demir Celik & 42 & TOASO & Tofas Oto Fab. \\
\hline 19 & FROTO & Ford Otosan & 43 & TRKCM & Trakya Cam \\
\hline 20 & GARAN & Garanti Bankasi & 44 & TSKB & Turkiye Sinai Kalkinma Bankasi \\
\hline 21 & GOLTS & Goltas Cimento & 45 & TUPRS & Tupras \\
\hline 22 & GOODY & Good-Year & 46 & VESTL & Vestel \\
\hline 23 & GUBRF & Gubre Fabrik. & 47 & YKBNK & Yapi ve Kredi Bankasi \\
\hline 24 & HURGZ & Hurriyet Gzt. & - & - & - \\
\hline
\end{tabular}


Table 2. Political Risk Factors Included in the Analysis

\begin{tabular}{|c|c|c|c|c|}
\hline Priority & $\begin{array}{l}\text { Political Risk } \\
\text { Variable }\end{array}$ & Code & $\begin{array}{l}\text { Upper } \\
\text { Limit }\end{array}$ & Explanation \\
\hline A & Government Stability & Gov & 12 & $\begin{array}{l}\text { A measure of both of the government's ability to carry out its } \\
\text { declared program(s), and its ability to stay in office. The risk rating } \\
\text { assigned is the sum of government unity, legislative strength, and } \\
\text { popular support. }\end{array}$ \\
\hline B & Socioeconomic Conditions & Soc & 12 & $\begin{array}{l}\text { A measure of the socioeconomic pressures at work in society that } \\
\text { could constrain government action or fuel social dissatisfaction. }\end{array}$ \\
\hline C & Investment Profile & Inv & 12 & $\begin{array}{l}\text { A measure of the factors affecting the risk to investment that are } \\
\text { not covered by other political, economic and financial risk } \\
\text { components. }\end{array}$ \\
\hline $\mathrm{D}$ & Internal Conflict & Int & 12 & $\begin{array}{l}\text { This is an assessment of political violence in the country and its } \\
\text { actual or potential impact on governance. }\end{array}$ \\
\hline$E$ & External Conflict & Ext & 12 & $\begin{array}{l}\text { The external conflict measure is an assessment both of the risk to } \\
\text { the incumbent government from foreign action, ranging from non- } \\
\text { violent external pressure (diplomatic pressures, withholding of } \\
\text { aid, trade restrictions, territorial disputes, sanctions, etc) to } \\
\text { violent external pressure (cross-border conflicts to all-out war). }\end{array}$ \\
\hline $\mathrm{F}$ & Corruption & Cor & 6 & $\begin{array}{l}\text { This is an assessment of corruption within the political system. } \\
\text { Such corruption is a threat to foreign investment for several } \\
\text { reasons: it distorts the economic and financial environment; it } \\
\text { reduces the efficiency of government and business by enabling } \\
\text { people to assume positions of power through patronage rather } \\
\text { than ability; and, last but not least, introduces an inherent } \\
\text { instability into the political process. }\end{array}$ \\
\hline G & Military in Politics & Mil & 6 & $\begin{array}{l}\text { A measure of the military's involvement in politics. Since the } \\
\text { military is not elected, involvement, even at a peripheral level, } \\
\text { diminishes democratic accountability. }\end{array}$ \\
\hline $\mathrm{H}$ & Religious Tensions & Rel & 6 & $\begin{array}{l}\text { A measure of religious tensions arising from the domination of } \\
\text { society and/or governance by a single religious group -- or a desire } \\
\text { to dominate -- in a way that replaces civil law by religious law, } \\
\text { excludes other religions from the political/social processes, } \\
\text { suppresses religious freedom or expressions of religious identity. }\end{array}$ \\
\hline I & Law \& Order & Law & 6 & $\begin{array}{l}\text { Two measures comprising one risk component. Each sub- } \\
\text { component equals half of the total. The "law" subcomponent } \\
\text { assesses the strength and impartiality of the legal system, and the } \\
\text { "order" subcomponent assesses popular observance of the law. }\end{array}$ \\
\hline J & Ethnic Tensions & Etn & 6 & $\begin{array}{l}\text { A measure of the degree of tension attributable to racial, national, } \\
\text { or language divisions. }\end{array}$ \\
\hline K & Democratic Accountability & Dem & 6 & $\begin{array}{l}\text { A measure of, not just whether there are free and fair elections, } \\
\text { but how responsive government is to its people. The less } \\
\text { responsive it is, the more likely it will fall. }\end{array}$ \\
\hline L & Bureaucracy Quality & Bur & 4 & $\begin{array}{l}\text { Institutional strength and quality of the bureaucracy is a shock } \\
\text { absorber that tends to minimize revisions of policy when } \\
\text { governments change. In low-risk countries, the bureaucracy is } \\
\text { somewhat autonomous from political pressure. }\end{array}$ \\
\hline & Total & & 100 & Total Political Risk (is not used in the analysis) \\
\hline
\end{tabular}

Source: ICRG, http://epub.prsgroup.com/list-of-all-variable-definitions, Accessed: 17.02.2016.

The data obtained from ICRG are utilized as of political risk indicators. ICRG evaluates 12 variables as political risk indicators and the sum of these variables represent the total political risk index pertain to a country for the related period. These indicators range from 0 to 100 showing that an increase in the indicator refers to the decrease in the related risk. Among the previous studies; Mei (1999), Bilson, Brailsford, and Hooper (2002), Yaprakli and Gungor (2007), Keles (2007), Sanlisoy and Kok (2010), Bekaert et al. (2012) and Ramady (2014) utilize the same indicators for their analysis. Unlike these studies, political risk indicator is taken not as a single total factor but 12 separate subcomponents in order to evaluate which variable is effective on stock returns. Before the analysis, all the subcomponents are adjusted as percentages and as to express an increase in the index as the increase in the related risk component. Thus, an index having $100 \%$ shows the highest risk while $0 \%$ means no risk. This adjustment helps these indeces operate in accordance with betas and helps findings to be interpreted more efficiently. Table 2 illustrates the list of political risk components in order of priority with the upper score limit assigned by ICRG. Descriptive statistics of the political risk components that are adjusted as to express percentages can be seen in Table 3 as well. 
In practice, proxy indices for the market are preferred although it is expected a market index to comprise all the assets in the market. Therefore, this study employs BIST100 index as a proxy for market index and analyzes the relationship between the monthly returns of companies traded on BIST, BIST100, and political risk components within the framework of CAPM. BIST 100 index is composed of 100 companies and taken as the basic index at Borsa Istanbul equity market. This index comprises 100 stocks traded on National Market and Real Estate Investment Trust (REIT) and Venture Capital Investment Trust companies traded on Collective Products Market and includes BIST 50 and BIST 30 index constituent companies (BIST, 2014).

Among the studies regarding Turkey (as of emerging markets), there are both those arguing that the CAPM is applicable on Turkish capital markets (Eraslan, 2011; Kavurmaci, 2009; Tanik, 2006 and Temizkaya, 2006) and those arguing that the model is inapplicable (Bozkurt, 2008 and Akagün, 2006). On the other hand, purpose of this study is not to test if CAPM is applicable on Turkish capital markets but rather "to utilize CAPM as a theoretical frame in investigating the relation between asset returns and political risks and benefit from its easiness to apply in explaining the relation between risk and return and taking market return into consideration as a benchmark". As a matter of fact, Comak (2009) takes advantage of CAPM in analyzing riskreturn relation of capital assets for Turkey, Dutta (2009) also employs CAPM in explaining the role of political regimes on asset returns in emerging markets and finally Bilson, Brailsford and Hooper (2002) examines the relation between political risks and stock returns in emerging markets within the framework of CAPM.

The usual method adopted in estimations related to CAPM or its derivatives is the "two-pass regression technique". This method was developed by Black, Jensen, and Scholes (1972) and Fama and Macbeth (1973) and has become one of the most preferred methods. According to this method, it is aimed to estimate the risk premiums and betas of assets. In the first pass of the method, beta estimations are made by the time series data of asset returns and market returns. In the second pass, cross-sectional data obtained by estimated betas and expected (average) returns of assets are included in the regression analysis in order to test the relation between returns and betas.

Table 3. Descriptive Statistics

\begin{tabular}{|l|c|c|c|c|c|c|c|c|c|c|c|c|}
\hline & COR & DEM & ETN & EXT & GOV & INT & INV & LAW & MIL & REL & SOC & BUR \\
\hline Mean & 60.101 & 31.018 & 64.141 & 29.356 & 26.599 & 35.942 & 34.596 & 32.281 & 60.437 & 31.271 & 59.154 & 49.116 \\
\hline Median & 58.333 & 33.333 & 66.666 & 29.166 & 25.000 & 33.333 & 33.333 & 33.333 & 66.667 & 33.333 & 54.167 & 50.000 \\
\hline Max. & 66.666 & 66.667 & 66.666 & 41.666 & 75.000 & 66.667 & 58.333 & 50.000 & 83.333 & 50.000 & 83.333 & 50.000 \\
\hline Min. & 50.000 & 8.333 & 58.333 & 12.500 & 8.333 & 12.500 & 8.333 & 25.000 & 33.333 & 16.667 & 41.667 & 25.000 \\
\hline Std. Dev. & 4.8631 & 20.531 & 3.8394 & 7.968 & 10.748 & 12.762 & 7.462 & 7.219 & 15.836 & 9.879 & 15.469 & 4.628 \\
\hline Skewness & -0.0661 & 0.732 & -0.8571 & -0.593 & 0.727 & 1.137 & -0.253 & 0.668 & -0.312 & 0.121 & 0.619 & -5.032 \\
\hline Kurtosis & 2.625 & 2.222 & 1.7347 & 2.217 & 4.420 & 4.076 & 8.243 & 2.608 & 2.230 & 2.752 & 1.767 & 26.322 \\
\hline Obs. & 198 & 198 & 198 & 198 & 198 & 198 & 198 & 198 & 198 & 198 & 198 & 198 \\
\hline
\end{tabular}

Since it is not intended to examine the possible effects of political risks on any certain company, in the first pass coefficients are determined by using the data of companies. It is the second pass in which any significant effect of political risks on expected returns of assets in the equity market is examined which is composing the basic motive of the study. In other words, point estimations of beta and political risks are made separately for each company's time series data in the first pass within the framework of CAPM. According to Gauss-Markov theorem, when there is no heteroscedasticity problem in a standard linear regression model, point estimation will be the best linear unbiased estimator (BLUE) (Shaffer, 1991: 269). It is accepted that point estimation provides more accurate results in average especially for the long-term analyses (Lehmann and Casella, 1998: 5). The model below is set in order to point estimate beta and political risks for each company in the first pass:

$$
\begin{gathered}
R_{i t}=\alpha_{i}+\beta_{i} R_{M t}+c_{i} \text { Gov }_{t}+d_{i} \text { Soc }_{t}+e_{i} \operatorname{Inv}_{t}+f_{i} \operatorname{Int}_{t}+g_{i} \text { Ext }_{t}+i_{i} \operatorname{Cor}_{t}+j_{i} \text { Mil }_{t} \\
+k_{i} \text { Rel }_{t}+l_{i} \text { Law }_{t}+m_{i} \text { Etn }_{t}+n_{i} \text { Dem }_{t}+o_{i} \text { Bur }_{t}+e_{i t}
\end{gathered}
$$

$i=1,2,3, \ldots, 47 ; \quad t=1,2,3, \ldots, 198$. 
Here;

$R_{i t}$ : return rate of stock $\mathrm{i}$ at the end of month $\mathrm{t}$,

$\alpha_{i}$ : constant term of stock i estimated at month $\mathrm{t}$,

$b_{i}$ : beta coefficient of stock i estimated at month $t$ (sensitivity to $R_{M t}$ ),

$R_{M t}$ : return rate of market portfolio (BIST 100) at the end of month $\mathrm{t}$,

$c_{i}, d_{i}, e_{i}, f_{i}, g_{i}, i_{i}, j_{i}, k_{i}, l_{i}, m_{i}, n_{i}, o_{i}$ : estimated sensitivity of stock $i$ to the related political risk variable (i.e. political risk coefficient), the Table 2,

$\operatorname{Gov}_{t}, \operatorname{Soc}_{t}, \operatorname{Inv}_{t}, \operatorname{Int}_{t}, \mathrm{Ext}_{t}, \operatorname{Cor}_{t}, \mathrm{Mil}_{t}, \operatorname{Rel}_{t}, \operatorname{Law}_{t}, \mathrm{Eth}_{t}, \operatorname{Dem}_{t}$, Bur $_{t}$ : political risk variables given in detail at

$e_{i t}$ : error term (unexplained part of dependent variable by independent variables).

According to CAPM, there is a linear relation between the beta and expected return of stocks. Therefore, coefficients (as the independent variables) obtained from the first pass compose the variables of the second pass together with the expected (average) return of companies (as the dependent variable). As a result, the question of "whether there is a statistically significant relation between the political risks and expected returns in equity markets in Turkey or not" will be able to be investigated thanks to the crosssectional data composed of 47 companies. This question is the basic motive of the research. Equation (4) illustrates the linear regression model for the cross-sectional data employed in the second pass:

$$
\begin{gathered}
E\left(R_{i}\right)=y_{0}+y_{1} \beta_{i}+y_{2} c_{i}+y_{3} d_{i}+y_{4} e_{i}+y_{5} f_{i}+y_{6} g_{i}+y_{7} i_{i}+y_{8} j_{i}+y_{9} k_{i}+y_{10} l_{i} \\
+y_{11} m_{i}+y_{12} n_{i}+y_{13} o_{i}+\varepsilon_{i}
\end{gathered}
$$

Here;

$i=1,2,3, \ldots, 47$

$E\left(R_{i}\right)$ : expected rate of return of stock $\mathrm{i}$,

$y_{0}$ : constant term (represents risk-free rate)

$b_{i}$ : beta coefficient estimated for the stock i (which was estimated in the Equation (3)),

$c_{i}, d_{i}, e_{i}, f_{i}, g_{i}, i_{i}, j_{i}, k_{i}, l_{i}, m_{i}, n_{i}, o_{i}$ : estimated sensitivity of stock i to the related political risk variable (which was estimated in the Equation (3)),

$y_{1}, y_{2}, y_{3}, y_{4}, y_{5}, y_{6}, y_{7}, y_{8}, y_{9}, y_{10}, y_{11}, y_{12}, y_{13}$ : coefficients showing to what degree stock $i$ is sensitive to the related risk variable,

$\varepsilon_{i}$ : error term (unexplained part of the dependent variable by independent variables).

\section{Findings}

In order to avoid spurious regression faced when the variables are not stationary (Gujarati, 2004: 792), unit root test is applied on the dataset before the first pass regression analysis is conducted. Because of the trend seen in time series data, the series may be nonstationary and cause spurious regression problem because of the high $\mathrm{R}^{2}$ value obtained despite the fact that there is literally no significant relation among the variables (Gujarati, 2004: 709). For this purpose, Augmented-Dickey Fuller (ADF) test is applied first. It is important the data to be stationary in order to get accurate results and avoid spurious relations among the series (Gujarati, 2009: 709-710; Buyukakin, Bozkurt and Cengiz, 2009: 108). According to the results of this test, if existence of any unit root, namely nonstationary, in the series is found, the data is adjusted by taking the logarithmic difference of the series. The hypotheses set for the test are as below:

$\mathrm{H}_{0}$ : There is a unit root problem in the series included in the research.

$\mathrm{H}_{1}$ : There is no unit root problem in the series included in the research. 
Since "Bureaucracy Quality (BUR)" has never changed but the first seven observation period, there could not be applied a meaningful unit root test on the data. Hence it is excluded from the research process as it will not be possible to get a significant result for this variable. Next, the correlation matrix is examined in order not to have a multicollinearity problem. It is important to exclude the variables with the correlation value above $80 \%$ from the analysis because it is not wanted variables to be perfectly collinear and to get robust findings (Keles, 2007: 230). According to the correlation matrix, there found no variable having $80 \%$ correlation with another in the analysis, hence the analysis is carried out with the current variables.

After aforementioned steps are applied on the data, model estimation process is conducted separately for each company. Steps applied in the first pass are as follows:

1. Examination of $F$ statistics and $R^{2}$ values for the significance of model,

2. Examination of serial correlation problem. The problem of serial correlation may often exist in time series data. Serial correlation also known as autocorrelation, is defined as the relation between error terms and their previous values over various time intervals and is not wanted for a robust regression analysis (Guris, Caglayan, and Guris, 2013: 199-200). Accordingly, Durbin-Watson statistics is checked and if it is around 2, that means there is no problem of serial correlation.

3. For the purpose of examining serial correlation problem, "Breusch-Godfrey Serial Correlation LM Test" is also applied. Hypothesis tests are as below:

$\mathrm{H}_{0}$ : There is no serial-correlation problem in the model.

$\mathrm{H}_{1}$ : There is a serial-correlation problem in the model.

In case of the test statistics being larger than $0,05 \mathrm{H}_{0}$ cannot be rejected and it is determined that serial correlation problem does not exist.

4. If serial correlation is determined, the model will be set again at $A R(1)$ (first order autoregressive process),

5. Collection and arrangement of all the coefficients obtained from the first pass as to compose the data of the second pass.

Those which are determined to have serial-correlation problem are AKBNK, ASELS, GOLTS, KCHOL, TUPRS and YKBNK. Necessary adjustments are made and the estimation process is continued as mentioned at step 4 regarding the first pass process. Table 4 shows the summary of the first step analysis conducted by each stock's time series data separately. Accordingly, average (expected) return, beta and political risk coefficients, $R^{2}$ values, significance of $F$ statistics and Durbin-Watson coefficients of the models set are presented. At the end of the beta coefficient estimation process, it is seen that these coefficients take values ranging between 0,53 and 1,16 . Findings show that systematic risks of companies are close to the systematic risk of the market portfolio and sensitive at a moderate level to the changes in market return. Among the companies being examined, companies having the lowest systematic risk estimations are Kartonsan (KARTN $-0,53$ ), Konya Cimento (KONYA - 0,69) from the manufacturing industry and Celebi (CLEBI-0,79) from the transportation sector. Companies having the highest systematic risk estimations are Yapi ve Kredi Bankasi (YKBNK - 1,16), Dogan Holding (DOHOL - 1,15) and Is Bankasi (ISCTR - 1,14) from the financial sector (Table 3). Therefore, it is seen that stocks of the financial sector companies move more sensitively to the changes in the market. These findings are compatible with those of Engle, Jondeau, and Rockinger (2012) investigating the systematic risk of companies in Europe. 


\begin{tabular}{|c|c|c|c|c|c|c|c|c|c|c|c|c|c|c|c|c|c|c|c|c|c|c|c|c|c|c|}
\hline $\begin{array}{l}0 \\
0 \\
0 \\
\tilde{n} \\
3\end{array}$ & $\begin{array}{l}m \\
\stackrel{n}{-1}\end{array}$ & $\begin{array}{c}\vec{J} \\
- \\
\end{array}$ & I & & $\begin{array}{l}m \\
\text { n }\end{array}$ & & & & & $\begin{array}{l}\infty \\
- \\
-1\end{array}$ & & & & 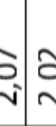 & 定 & 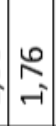 & 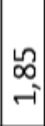 & & & & & & & & & $\begin{array}{l}\stackrel{n}{N} \\
-1 \\
\end{array}$ \\
\hline 空节 & $\begin{array}{l}0 \\
0 \\
0 \\
0\end{array}$ & & : & & \begin{tabular}{l}
8 \\
\hdashline \\
$\circ$
\end{tabular} & : & '. & : & : & : & కై & s. & ș. & & 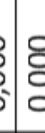 & : & : & \begin{tabular}{l}
8 \\
\hdashline \\
\hdashline \\
\end{tabular} & & & & 잉 & $\begin{array}{l}8 \\
\\
0 \\
\end{array}$ & $\begin{array}{l}8 \\
8 \\
0 \\
0\end{array}$ & & 8 \\
\hline$\approx$ & $\begin{array}{l}\text { Lొ } \\
\text { h. }\end{array}$ & $\begin{array}{l}n \\
0 \\
0\end{array}$ & 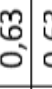 & $\begin{array}{l}0 \\
0 \\
0 \\
0\end{array}$ & $\begin{array}{l}n \\
0 \\
0\end{array}$ & $\begin{array}{l}n \\
0 \\
0\end{array}$ & ב: & 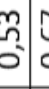 & 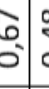 & sol & $\begin{array}{l}n \\
n \\
c\end{array}$ & \pm & 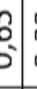 & $m=$ & 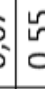 & {$\left[\begin{array}{l}m \\
\tilde{C} \\
0\end{array}\right.$} & $\begin{array}{l}-1 \\
0 \\
0\end{array}$ & $\begin{array}{l}6 \\
0 \\
0\end{array}$ & $\begin{array}{c}\mathbf{a} \\
\vdots \\
0\end{array}$ & 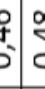 & 贶 & $\begin{array}{l}\tilde{n} \\
0 \\
0\end{array}$ & $\begin{array}{c}-\vec{m} \\
0^{\circ}\end{array}$ & $\begin{array}{c}\text { m } \\
\text { o. } \\
\text { | }\end{array}$ & & กิ \\
\hline ర్ & & ִָ & 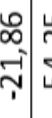 & 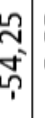 & $\begin{array}{l}\infty \\
\infty \\
\infty\end{array}$ & 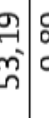 & \begin{tabular}{l}
8 \\
\hdashline \\
\hdashline
\end{tabular} & $\begin{array}{l}a \\
c \\
m\end{array}$ & 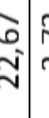 & 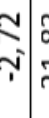 & $\begin{array}{l}0 \\
0 \\
0\end{array}$ & $\begin{array}{l}n \\
v \\
v\end{array}$ & $\begin{array}{l}0 \\
0 \\
\end{array}$ & 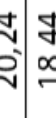 & & $\begin{array}{l}0 \\
-1 \\
m \\
\dot{y}\end{array}$ & $\mid \begin{array}{l}\tilde{0} \\
\\
\end{array}$ & $\begin{array}{l}\stackrel{0}{2} \\
\stackrel{9}{r}\end{array}$ & \begin{tabular}{l|l}
0 & \\
0 \\
\hdashline \\
\hdashline \\
\end{tabular} & & & 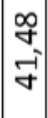 & 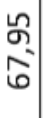 & $\begin{array}{l}\infty \\
\infty \\
0^{\circ}\end{array}$ & & $\begin{array}{c}\vec{m} \\
\text { ने }\end{array}$ \\
\hline$\underset{\propto}{\ddot{~}}$ & $\begin{array}{l}6 \\
\varrho \\
\\
1\end{array}$ & 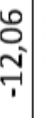 & 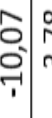 & 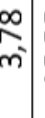 & \begin{tabular}{c|c}
$\infty$ & \\
$m$ & \\
- & \\
\hdashline & \\
\hdashline
\end{tabular} & $\begin{array}{l}0 \\
\end{array}$ & 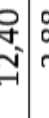 & $\begin{array}{c}\infty \\
\infty \\
\infty \\
\end{array}$ & 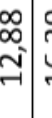 & 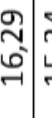 & 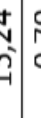 & 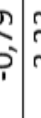 & & 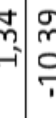 & 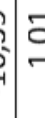 & 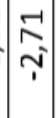 & 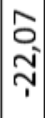 & 今ે & $\begin{array}{lll}\infty \\
m\end{array}$ & & 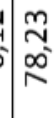 & 点 & 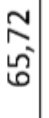 & (-) & & 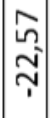 \\
\hline$\vec{\Sigma}$ & $\begin{array}{l}\infty \\
0 \\
0 \\
1\end{array}$ & 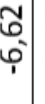 & $\begin{array}{c}n \\
\sim \\
\sim\end{array}$ & $\mid \begin{array}{l}0 \\
\infty \\
0 \\
0\end{array}$ & $\begin{array}{ll}0 & : \\
0 \\
0\end{array}$ & $\begin{array}{l}x^{\infty} \\
0 \\
0\end{array}$ & mi & 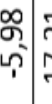 & 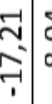 & $\begin{array}{l}\mathbf{S} \\
\infty \\
\infty \\
1\end{array}$ & : & $\begin{array}{l}n \\
\text { Sn }\end{array}$ & $n$ & 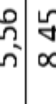 & 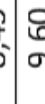 & $\stackrel{7}{-}$ & $\begin{array}{l}\text { g } \\
\text { ò }\end{array}$ & 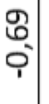 & $\begin{array}{l}0 \\
0 \\
0 \\
0\end{array}$ & & & 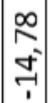 & $\begin{array}{c}\infty \\
m \\
\infty \\
m \\
p\end{array}$ & 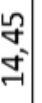 & & $\left|\begin{array}{l} \\
\infty \\
-1 \\
-1\end{array}\right|$ \\
\hline$\frac{3}{5}$ & $\begin{array}{l}n \\
0 \\
\tilde{n} \\
\end{array}$ & 号 & 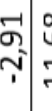 & $\begin{array}{l}\infty \\
0 \\
- \\
-1\end{array}$ & 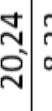 & $\begin{array}{c}\underset{Z}{n} \\
\infty\end{array}$ & 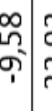 & $\begin{array}{l}\tilde{N} \\
\tilde{n}\end{array}$ & $\begin{array}{l}m \\
\tilde{N} \\
\end{array}$ & 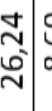 & $\begin{array}{l}0 \\
0 \\
0 \\
0\end{array}$ & 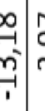 & & 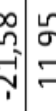 & \% & $\begin{array}{l}-1 \\
\tilde{7} \\
7\end{array}$ & $\begin{array}{l}m \\
\hat{n} \\
\end{array}$ & 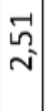 & 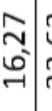 & & & 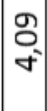 & 年 & $\begin{array}{l}0 \\
\text { - } \\
\text { m. }\end{array}$ & & $\mid \begin{array}{c}0 \\
-1 \\
y\end{array}$ \\
\hline$\underline{\underline{z}}$ & $\stackrel{m}{\sim}$ & 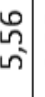 & $\begin{array}{c}\tilde{m} \\
\text { ตे }\end{array}$ & $\begin{array}{l}3 \\
-7 \\
-1\end{array}$ & \begin{tabular}{c|l}
$\infty$ & \\
$n^{7}$ &
\end{tabular} & 焉: & 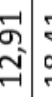 & 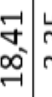 & $\begin{array}{c}n \\
m \\
m\end{array}$ & $\begin{array}{l}0 \\
0 \\
0\end{array}$ & \begin{tabular}{l}
7 \\
\hdashline \\
\hdashline
\end{tabular} & $\begin{array}{l}n \\
\text { nat } \\
\text { s. }\end{array}$ & 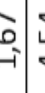 & 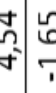 & $\frac{10}{2}$ & 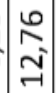 & 孚 & $\begin{array}{c}\stackrel{0}{m} \\
\sim \\
T\end{array}$ & \begin{tabular}{l}
\multirow{2}{*}{} \\
6 \\
\end{tabular} & $\begin{array}{l}1 \\
\vdots \\
\vdots\end{array}$ & $=\frac{9}{2}$ & $\mid \begin{array}{l}0 \\
0 \\
0 \\
1\end{array}$ & $\begin{array}{l}\mathbf{D} \\
\text { i }\end{array}$ & 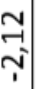 & & \begin{tabular}{l}
$\infty$ \\
\multirow{1}{*}{} \\
$m$
\end{tabular} \\
\hline$\underline{\underline{\mathbf{z}}}$ & $\begin{array}{l}\text { శ్ } \\
\text { Tे }\end{array}$ & $\begin{array}{l}-1 \\
\infty \\
\mp \\
\mp\end{array}$ & 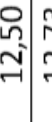 & \begin{tabular}{l}
$m$ \\
\multirow{2}{*}{} \\
$\bar{r}$
\end{tabular} & 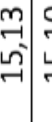 & 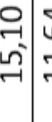 & 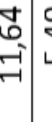 & $\begin{array}{l}g \\
g \\
\vdots\end{array}$ & $\stackrel{\vec{m}}{\stackrel{-}{=}}$ & 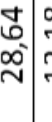 & 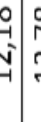 & 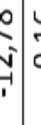 & 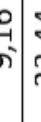 & 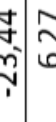 & $\mid$ & $\begin{array}{l}0 \\
0 \\
0 \\
0\end{array}$ & न. & $\begin{array}{l}\stackrel{n}{n} \\
\rightarrow-1\end{array}$ & $\begin{array}{c}-1 \\
m \\
\infty \\
-1\end{array}$ & $\begin{array}{l}0 \\
: \\
:\end{array}$ & 省 & 옥 & $\begin{array}{l}\tilde{L} \\
m \\
\vec{f}\end{array}$ & $\begin{array}{l}-1 \\
\\
\end{array}$ & & $\mid$\begin{tabular}{l}
0 \\
\multicolumn{2}{c}{} \\
$\delta$
\end{tabular} \\
\hline రે & \begin{tabular}{l}
\multirow{1}{1}{} \\
0
\end{tabular} & $\begin{array}{l}\stackrel{2}{2} \\
m \\
\end{array}$ & $\begin{array}{l}0 \\
\text { r. } \\
\text { Tे }\end{array}$ & $\begin{array}{c}0 \\
\stackrel{8}{1} \\
-1\end{array}$ & $\underset{\sim}{ \pm}$ & $\begin{array}{l}\infty \\
\infty \\
\infty \\
\vdots \\
0\end{array}$ & $\begin{array}{l}\text { ch } \\
m^{2}\end{array}$ & 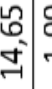 & & 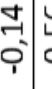 & ? & 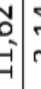 & 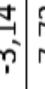 & $=\alpha$ & $\left\{\begin{array}{l}n \\
m\end{array}\right.$ & $\mid \begin{array}{l}n \\
n^{\prime}\end{array}$ & f & $\begin{array}{l}\infty \\
0 \\
\uparrow \\
\uparrow\end{array}$ & $\begin{array}{l}0 \\
\infty \\
\\
\end{array}$ & 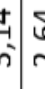 & न & 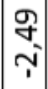 & $\begin{array}{l}\text { f } \\
\text { ít }\end{array}$ & 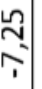 & $\begin{array}{l}0 \\
m \\
\text { t } \\
\end{array}$ & $\begin{array}{c}\text { 어 } \\
\infty\end{array}$ \\
\hline 卓 & 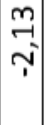 & $\begin{array}{c}\text { बे } \\
\stackrel{-}{-}\end{array}$ & $\begin{array}{l}\infty \\
\infty \\
-1 \\
-1 \\
-1\end{array}$ & $\begin{array}{c}0 \\
0 \\
0 \\
0\end{array}$ & 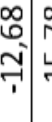 & 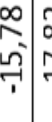 & $\begin{array}{l}0 \\
\infty \\
\\
\end{array}$ & 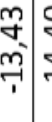 & 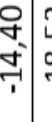 & 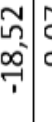 & (ד) & 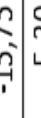 & :? & 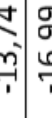 & $\frac{7}{8}$ & $\begin{array}{l}0 \\
0 \\
\text {. } \\
1\end{array}$ & ר્? & $\begin{array}{c}\text { 吾 } \\
\text {-i }\end{array}$ & 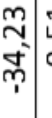 & 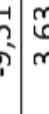 & 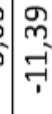 & 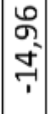 & \begin{tabular}{l}
$\circlearrowright$ \\
\multirow{T}{*}{}
\end{tabular} & $\begin{array}{l}\infty \\
0 \\
+\end{array}$ & & $\begin{array}{l}\stackrel{9}{m} \\
\end{array}$ \\
\hline 点 & $\begin{array}{l}\stackrel{ \pm}{A} \\
\stackrel{5}{ }\end{array}$ & 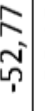 & 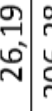 & 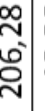 & 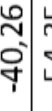 & 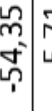 & 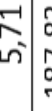 & \begin{tabular}{l|l}
$\infty$ & \\
$\infty$ & 0 \\
$-\infty$ & 0 \\
-1 & 0
\end{tabular} & 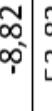 & 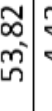 & f & $\begin{array}{l}1 \\
0 \\
0\end{array}$ & $\begin{array}{l}0 \\
0 \\
0\end{array}$ & 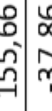 & 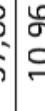 & & $\begin{array}{l}\text { N } \\
\text { ने }\end{array}$ & 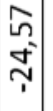 & 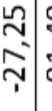 & & & 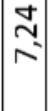 & $\begin{array}{l}\hat{0} \\
0 \\
-1\end{array}$ & 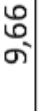 & & $\left|\begin{array}{l}n \\
0 \\
0 \\
0 \\
m\end{array}\right|$ \\
\hline$\sum_{\text {㟧 }}$ & $\begin{array}{l}0 \\
0 \\
0 \\
1\end{array}$ & $\begin{array}{l}0 \\
\infty \\
\mathbb{T} \\
\end{array}$ & \begin{tabular}{c|c}
$\tilde{n}$ & \\
$\sim$ &
\end{tabular} & ㄴ & $\begin{array}{l}\text { 负 } \\
+\end{array}$ & $\begin{array}{c}0 \\
0 \\
0 \\
0\end{array}$ & 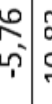 & \begin{tabular}{l}
$\infty$ \\
$\infty$ \\
0 \\
\hdashline \\
\end{tabular} & $\begin{array}{l}\infty \\
\infty \\
\infty \\
\infty \\
1\end{array}$ & 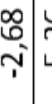 & ri & vi & v & గొ & ית & $\left(\begin{array}{l}\infty \\
\infty \\
0 \\
\varphi^{-}\end{array}\right.$ & $\begin{array}{l}\mathbb{N} \\
-1 \\
-1\end{array}$ & $\begin{array}{l}\hat{L} \\
\tilde{n} \\
m\end{array}$ & $\begin{array}{l}n \\
m\end{array}$ & 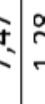 & $\begin{array}{l}0 \\
\text { I } \\
7\end{array}$ & 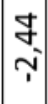 & $\begin{array}{c}-1 \\
0 \\
0 \\
1\end{array}$ & 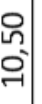 & & $\begin{array}{l}\text { O } \\
\text { พ }\end{array}$ \\
\hline 엉 & $\begin{array}{l}m \\
\tilde{n} \\
0 \\
\infty\end{array}$ & बे. & 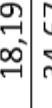 & $\begin{array}{l}\hat{b} \\
\text { m. } \\
\end{array}$ & $\begin{array}{l}\text { vै } \\
\text { m }\end{array}$ & \begin{tabular}{l|l} 
& \\
- & \\
$\infty$ & \\
7 &
\end{tabular} & : & 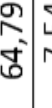 & 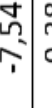 & $\begin{array}{l}\infty \\
m \\
\sigma^{\infty}\end{array}$ & $\begin{array}{c}0 \\
0 \\
n\end{array}$ & $\begin{array}{l}c \\
\\
\end{array}$ & 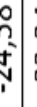 & $\begin{array}{c}\mathbf{D} \\
- \\
-1\end{array}$ & $\left\{\begin{array}{l}\infty \\
\infty \\
\infty\end{array}\right.$ & $\begin{array}{l}\infty \\
\infty \\
n^{0}\end{array}$ & $\begin{array}{l}n \\
0 \\
-i \\
p\end{array}$ & 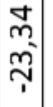 & $\begin{array}{ll}0 \\
\text { in }\end{array}$ & & {$\left[\begin{array}{ll}n \\
0 \\
0\end{array}\right.$} & $\mid$\begin{tabular}{l}
$\infty$ \\
\multirow{2}{7}{} \\
-1
\end{tabular} & $\begin{array}{l}\overrightarrow{2} \\
\tilde{m} \\
0 \\
1\end{array}$ & 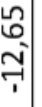 & & $\begin{array}{l}7 \\
7 \\
0 \\
6\end{array}$ \\
\hline さొ & $\begin{array}{l}\hat{A} \\
0\end{array}$ & $\begin{array}{l}n \\
-i \\
-i\end{array}$ & $\begin{array}{ccc}0 & & 3 \\
0 & & \end{array}$ & $\begin{array}{l}\text { o. } \\
\text { - }\end{array}$ & $\begin{array}{l}n \\
\vdots \\
0\end{array}$ & $\begin{array}{l}0 \\
\vdots \\
\vdots \\
0\end{array}$ & $\overrightarrow{0}$ & $\begin{array}{l}n \\
\vdots \\
\sigma\end{array}$ & \begin{tabular}{c|c}
$\infty$ & \\
$\infty$ \\
0 \\
0
\end{tabular} & \begin{tabular}{c|c}
-1 & $\vdots$ \\
0 \\
0
\end{tabular} & $\begin{array}{l}0 \\
0 \\
0 \\
\vdots\end{array}$ & 0 & & $\begin{array}{c}n \\
0 \\
0\end{array}$ & $\sigma$ & б. & ᄋ్ & 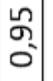 & $\begin{array}{l}=1 \\
\Rightarrow 1\end{array}$ & $=$ & $\begin{array}{l}\mathscr{2} \\
0 \\
0\end{array}$ & $\Rightarrow$ & $\begin{array}{l} \pm \\
-i\end{array}$ & बू. & $\begin{array}{l} \pm \\
-i\end{array}$ & $\mid \begin{array}{l}\infty \\
\infty \\
0 \\
0\end{array}$ \\
\hline 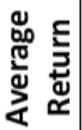 & $\begin{array}{c}0 \\
0 \\
i\end{array}$ & & $\begin{array}{l}7 \\
-7\end{array}$ & ת. & 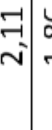 & \begin{tabular}{c}
$\infty$ \\
$\infty$ \\
\hdashline \\
\hdashline
\end{tabular} & $f$ & $\begin{array}{c}\infty \\
\stackrel{\infty}{n} \\
\end{array}$ & $\begin{array}{c}\stackrel{2}{a} \\
\rightarrow-\end{array}$ & ' & & 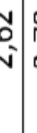 & & \begin{tabular}{c|c}
$\infty$ \\
i
\end{tabular} & 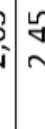 & $\begin{array}{l}2 \\
\sim\end{array}$ & $\begin{array}{l}\stackrel{0}{0} \\
i\end{array}$ & $\begin{array}{c}n \\
\infty \\
i\end{array}$ & $\begin{array}{ll}= & = \\
m & 0\end{array}$ & $\begin{array}{l}4 \\
\vdots \\
4\end{array}$ & $\underset{m}{7}$ & $\begin{array}{l}0 \\
1 \\
i\end{array}$ & 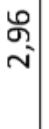 & & & $\begin{array}{l}\infty \\
\stackrel{\infty}{\rightarrow}\end{array}$ \\
\hline ัㅇํ & 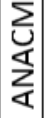 & $\begin{array}{l}\text { 㒸 } \\
\text { a } \\
\frac{1}{4}\end{array}$ & $\simeq$ & & $\frac{2}{\frac{c}{4}}$ & 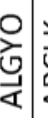 & 总 & , & $\mathbb{x}$ & & & & & & & & & o & 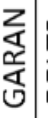 & & 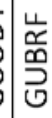 & & $\begin{array}{l}\stackrel{4}{\overrightarrow{⿱ 山}} \\
\text { 至 }\end{array}$ & & $\frac{\Upsilon}{\underline{w}}$ & $\sum_{\underline{\Delta}}^{U}$ \\
\hline
\end{tabular}




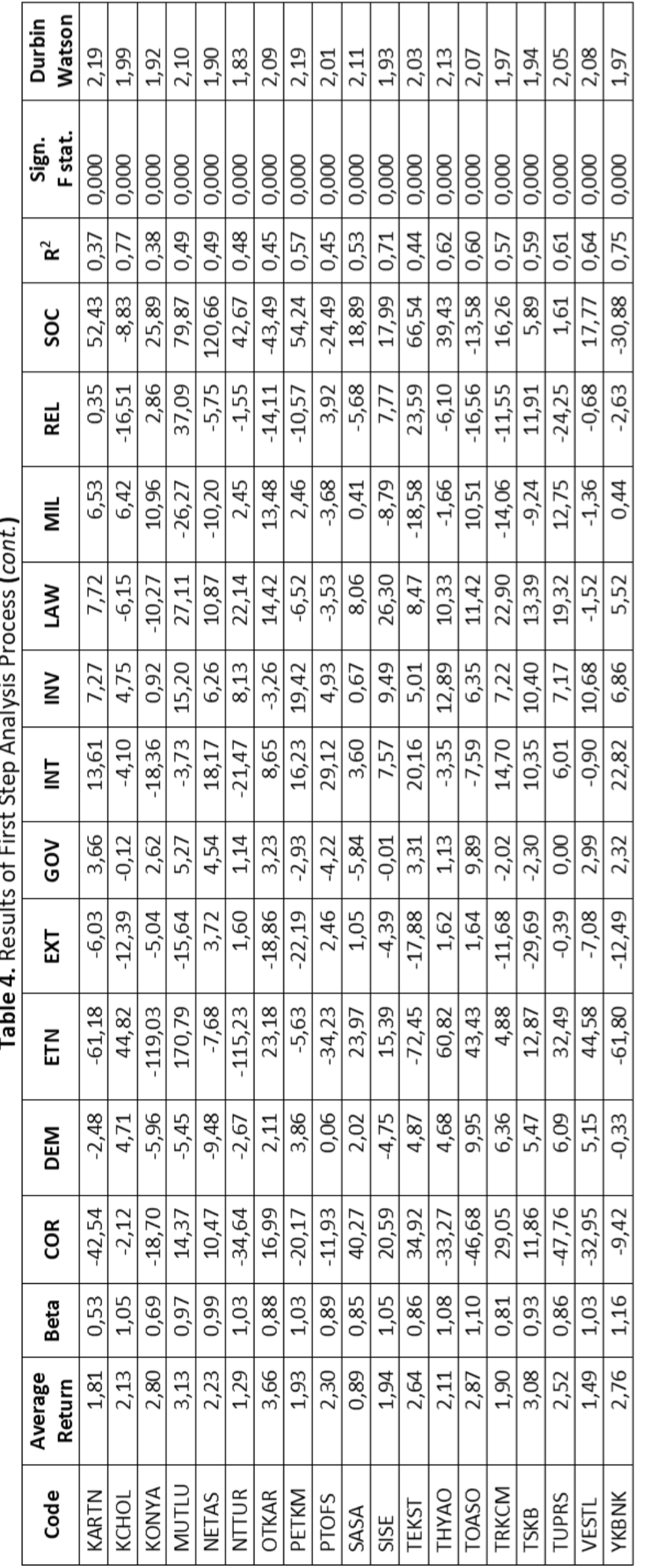


Findings of the first pass compose the variables of the second pass. Here only one regression analysis is made by using the cross-sectional data obtained. At the end of this pass, questions below are going to be able to be answered:

1. Do political risks have a statistically significant effect on the evaluation of asset returns?

2. Which political risk components have a statistically significant effect on the evaluation of asset return?

3. In what direction do the risk factors affect the expected (average) returns of assets?

4. Are the findings pertaining to Turkey compatible with the theories?

Thus in the second pass regression process, first analysis of the cross-sectional data regarding the relation between expected return (dependent variable) and political risks and beta coefficients (independent variables) is conducted. Siginificance of the model and the coefficients, multicollinearity problem, serialcorrelation problem (by Breusch-Godfrey Serial Correlation LM test), normality (by Jarque-Bera test), heteroscedasticity problem (by Breusch-Pagan-Godfrey test) are examined respectively. The model is then rearranged and tested in case of necessity according to the findings of the model.

At the first application of the model by the whole variables included, $R^{2}$ value is calculated as 0,46892 meaning that the current variables explain the expected return at $47 \%$ level. On the other hand, considering the significance of the coefficients, it is found that the variables of external conflict (EXT), government stability (GOV) and socioeconomic conditions (SOC) are not statistically significant. Here multicollinearity problem is tested. At the end of this test, it is found to be a multicollinearity problem in the current dataset. The existence of serial-correlation problem is tested by Breusch-Pagan-Godfrey test. According to the findings, there found no serial-correlation problem in the dataset. Finally, as the significance of Jarque-Bera statistics $(0,411975)$ is larger than 0,05 , the model means to be normally distributed. In order to get rid of the problems determined at the end of the tests applied, the model needs to be reformed. For this purpose, statistically insignificant variables are removed from the model at each turn and all the tests carried out respectively.

Following part presents the results of the final version of the model with robust statistics.

Table 5. Results of Cross-Sectional Regression Analysis (Dependent Variable: Average Return)

\begin{tabular}{|l|c|c|c|c|}
\hline \multicolumn{1}{|c|}{ Variable } & Coefficient & Std. Deviation & t-statistics & Significance \\
\hline BETA & 0.861155 & 0.495905 & 1.736534 & 0.0904 \\
\hline EXT & -0.037165 & 0.006857 & -5.419956 & 0.0000 \\
\hline GOV & 0.032523 & 0.013301 & 2.445085 & 0.0191 \\
\hline INT & -0.015619 & 0.005966 & -2.618092 & 0.0125 \\
\hline MIL & -0.009915 & 0.004925 & -2.013248 & 0.0510 \\
\hline C & 1.215185 & 0.475652 & 2.554775 & 0.0146 \\
\hline$R^{2}$ & 0,498928 & \multicolumn{2}{|l|}{} & 2,042422 \\
\hline Adjusted R $R^{2}$ & 0,421840 & \multicolumn{2}{|l|}{ Durbin-Watson statistics } & 0,000085 \\
\hline F statistics & 6,472192 &
\end{tabular}

At the end of the final analysis, variables determined to have a statistically significant effect on the expected (average) returns of the assets traded on Borsa Istanbul equity market are "external conflict (EXT)", "government stability (GOV)", "internal conflict (INT)" and "military in politics (MIL)". Also, there is a statistically significant relation between beta and expected returns. Accordingly, $1 \%$ change in external conflict risk causes expected return to change $-0,0371$ point. $1 \%$ change in internal conflict risk causes expected return to change nearly $-0,0156$ point. $1 \%$ change in risks regarding government stability cause expected return a 0,0325 point change. $1 \%$ change in risks regarding military in politics cause expected return to change $-0,0099$ point. It is seen that standard deviations in political risk variables have quite small values meaning that any movement in aforementioned variables will have smaller deviations in political risks. Also, it is seen in Table 5 that an increase in beta ( 1 point increase) causes expected returns to increase $(0,8611)$ which means findings of Turkey are compatible with the theory. CAPM also argues that one should expect a higher return in return for a higher risk. Among the political risk variables, only an increase in the risks 
regarding government stability causes expected return to increase. On the contrary, an increase in the other political risk variables causes expected returns to decrease.

It is seen that there is no multicollinearity problem in the final version of the model (Table 6).

Table 6. Test of Multicollinearity Problem

\begin{tabular}{|c|c|c|c|}
\hline Variable & Coefficient Variance & Uncentered VIF & Centered VIF \\
\hline BETA & 0.245921 & 118.0191 & 1.115714 \\
\hline EXT & $4.70 \mathrm{E}-05$ & 3.634552 & 1.138001 \\
\hline GOV & 0.000177 & 1.310757 & 1.138391 \\
\hline INT & $3.56 \mathrm{E}-05$ & 1.846022 & 1.386941 \\
\hline MIL & $2.43 \mathrm{E}-05$ & 1.256643 & 1.231917 \\
\hline C & 0.226245 & 124.4270 & $\mathrm{NA}$ \\
\hline AR(1) & 0.017871 & 1.053147 & 1.053036 \\
\hline
\end{tabular}

Breusch-Pagan-Godfrey Test helps to check if there is any heteroscedasticity problem in the model. Since significance levels are higher than $0.05, \mathrm{H}_{0}$ cannot be rejected and that means there is no heteroscedasticity problem in this model (Table 7).

Table 7. Test of Heteroscedasticity Problem

\begin{tabular}{|c|c|c|c|}
\hline \multicolumn{4}{|c|}{ Hypotheses: } \\
\hline \multicolumn{4}{|c|}{$\begin{array}{l}\mathrm{H}_{0}: \text { There is no heteroscedasticity in the model. } \\
\mathrm{H}_{1}: \text { There is a heteroscedasticity in the model. }\end{array}$} \\
\hline F statistics & 0.849570 & Significance $F(5,40)$ & 0.5231 \\
\hline Obs* $R^{2}$ & 4.416060 & Significance Chi-square (5) & 0.4912 \\
\hline
\end{tabular}

According to the serial-correlation test (by the Breusch-Godfrey Serial Correlation LM Test) for the final model, $\mathrm{H}_{0}$ cannot be rejected as significance levels are higher than 0,05 . That means there is no serial correlation problem in this model (Table 8).

Table 8. Results of Serial-Correlation Test

\begin{tabular}{|l|l|l|r|}
\hline Hypotheses: \\
\hline$H_{0}:$ There is no serial-correlation problem in the model. \\
$\mathrm{H}_{1}$ : There is a serial-correlation problem in the model. \\
\hline $\mathrm{F}$ statistics & 0.092450 & Significance $\mathrm{F}(1,33)$ & 0.7627 \\
\hline Obs $^{2} \mathrm{R}^{2}$ & 0.111641 & Significance Ki-kare (1) & 0.7383 \\
\hline
\end{tabular}
follows:

Finally, results of the normality test are shown in Table 9. Hypotheses related to this test are as

$\mathrm{H}_{0}$ : The model is normally distributed.

$\mathrm{H}_{1}$ : The model is not normally distributed.

Table 9. Test of Normality Results

\begin{tabular}{|l|l|l|l|}
\hline Series: Residuals & Sample: 247 & Observations: 46 & \\
\hline \multicolumn{4}{|l|}{} \\
\hline Mean: & $-2.27 e-15$ & Std. Dev.: & 0.428390 \\
\hline Median: & -0.042343 & Skewness: & -0.005541 \\
\hline Maximum: & 0.829752 & Kurtosis: & 2.237452 \\
\hline Mimimum: & -0.897363 & & \\
\hline \multicolumn{5}{|l|}{} \\
\hline Jarque-Bera: & 1.114737 & Probability: & 0.572714 \\
\hline
\end{tabular}


Since Jarque-Bera statistics is higher than $(0,572714) 0.05, \mathrm{H}_{0}$ cannot be rejected. The model is normally distributed (Table 9).

As a result of this analysis which investigates the effects of political risks on stock returns in Turkey, the equation (5) is obtained:

$$
\begin{gathered}
E\left(R_{i}\right)=1.215185+0.861155 \beta_{i}-0.037165 E X T+0.032523 G O V-0.015619 I N T \\
-0.009915 M I L
\end{gathered}
$$

This equation shows that among the political risk factors, "external conflict", "internal conflict", "government stability" and "military in politics" have statistically significant effect on the expected returns of assets in equity markets. While the factor affecting the expected returns the most is the "external conflict $(E X T)$ ", the direction of this effect is negative. Only an increase in the political risk factor "government stability (GOV)" has a positive effect on the expected returns. The factor affecting the expected returns the least is "military in government (MIL)".

On the other hand, there is a positive relation between beta and expected return meaning that a 1 point increase in the beta causes expected returns to increase 0,861155 points. However, standard deviation of the beta coefficient is 0,495905 and that means beta of the companies included in the analysis has $49,59 \%$ of deviation and there is not a homogeneous distribution among the beta values. About this issue, Daves, Ehrhardt, and Kunkel (2000) argues that in condition of choosing daily data, standard deviation of the beta will get smaller and will help to get more precise findings. However, because of the limitations of getting and arranging the daily data, it is used monthly data in this analysis instead.

When we compare the results of this study with those examining the relation between financial markets and political risks, Bilson et al. (2002), He (1999), Keles (2007), Kim and Mei (2001), Yaprakli and Gungor (2007), Erkocak and Cam (2015) also seem to find political risks to be effective on asset returns. However, this effect cannot be explained precisely. Besides being compatible with the previous studies, this study also determines which and in what direction political risk factors are effective on asset returns.

With reference to the previous studies, it is reasonable to expect political risks to be effective on security markets in the developing countries, however taking subcomponents separately, it is seen that different political risk subcomponents may stand out for each country. Only the risk of "military in government" seems to be a prominent risk factor peculiar to Turkey. This finding may be considered as the reflection of the various coup and post-modern coup movements occurring nearly each decade in Turkey.

Contrary to the idea of expecting a higher return for bearing a higher risk, it is found that the expected returns are not affected in the positive direction by the political risk factors except the risk of "government stability". Therefore the findings seem to be compatible with those of Dutta (2009) and Henderson and Rodriguez (2008). On the other hand, Pastor and Veronesi (2010; 2012), found that the higher the uncertainties the higher the risk premiums in which they study the reflection of uncertainty in government policies on stock prices.

Likewise, Fitzsimons and Sun (2012) also studied the effect of government stability, socioeconomic conditions, investment profile, internal conflict and external conflict factors obtained by ICRG on stock returns and found that economically less developed countries tend to be more exposed to these risks. It is also found that each country is exposed to another political risk variable more than the others. "Internal conflict" is negatively affecting all the countries included in the analysis. On the other hand, our study has also found that internal conflict negatively affects asset returns. Besides, according to our findings, the factor to be the most effective on expected returns appears to be the "external conflict" risk in absolute terms.

Among the 4 political risk factors determined to be effective on expected returns of stocks, only the risk of "government stability" emerges under the control of the government. The other factors, however, are beyond the control of the government. It is also another remarkable finding that only an increase in the risk factor (government stability) being under the control of government cause an increase in the expected 
returns. The aforementioned positive effect on the expected returns could be arising from an increase in the risk factors regarding an instability in government policies or an instability of governments' remaining in power and therefore causing investors to expect a higher risk premium for jeopardizing the proprietary rights of the investors. On the other hand, the negative effect of the remaining risk factors on the expected returns could be resulting from the exposure of stock markets, by their very nature, to rapid capital flows and therefore being oversensitive against any confidence lost.

Despite the lack of any assessment regarding the efficiency of markets in the other similar studies, if we consider Turkish stock market is approximating to "semi-strong market" properties compared to EU countries (Sengonul and Degirmen, 2001: 583-584), we can conclude that these findings are reflecting the idiosyncrasy of the market rather than speculative features.

These findings have various applications. First, it shows that not only betas but also identified political risk factors should be taken into account regarding the investment decisions in the financial markets in Turkey.

Correctly identifying which factors are effective on the return of investments would help investors make better portfolio diversification decisions and thus have higher returns. In addition, since expected returns are found to be associated with political risks, it means that multinational corporations can benefit from such assets in order to hedge against political risk as of their investment strategies.

Finally, since risks related to government stability are effective on expected returns, this also means that policy makers need to take the reflection of their decisions on financial markets into account as well.

\section{Summary and Conclusions}

While financial globalization and liberalization movement provide new investment opportunities for those aiming maximum return and minimum risk combination, it also changes the factors affecting returns expected by the investors and increases the variety and the size of the risk they are exposed to. In such an environment, depending on the risk especially the capital seems to flow from one country to another rapidly and in large amounts. In case of insecurity, it was an ordinary experiment for many countries to have crisis due to rapid and short-term capital outflows. Political variables, on the other hand, have an important role in assuring the environment of trust and the stability of investments in a country. In case of instability in politics or after the decisions taken by the government, there seem to be volatilities especially in the capital flows and the stock markets react to these changes.

Within the scope of increasing expropriation policies of developing countries and their claiming rights on the income and assets of investors during 1970s, the issue of political risk has started to be among the agenda of economic researchers. However, various research results show that political risks can arise from both government policies and the internal and external environmental factors beyond the control of government and thus cause investors to bear losses. Hence, in case of taking better investment decisions, it is important not to ignore political risks.

Despite the fact of being a contradictive model in terms of its assumptions and results, Capital Asset Pricing Model is still one the most preferred asset pricing models. The CAPM tries to explain expected return of financial assets by beta coefficient. Accordingly, there exists a linear relation between the beta and the expected return and it is expected an asset's expected return to increase as the asset's beta, namely its systematic risk, increases. Using the data of Turkey, this research utilized CAPM model in which two-step regression analysis is applied. The basic component making the study distinguishing is that the political risk is considered under 12 subcomponent and using CAPM as a base in their being associated with the expected return of stocks. In the study, dollar-based monthly average returns of 47 companies that are also composing BIST100 index, are taken into account for the period of 1997: January and 2013: June. Dollar-based monthly return percentage of BIST100 index is used as an indicator of market return for the aforementioned period. Finally, as of political risk factor, 12 political risk indicators by ICRG are used. 
According to the findings, there found to be a linear and positive relation between the beta and expected return in Turkish financial markets which is also compatible with CAPM. On the other hand, this finding seems to be statistically significant at only $10 \%$ level.

Regarding political risks as of the main part of the study, among the 12 variables being handled only 4 variables are determined to have a statistically significant effect on expected return of financial assets in Turkey. These are the factors of internal conflict, external conflict, government stability and military in politics. Among these variables, external conflict and government stability are the most effective, while military in politics is the least. In return for an increase in government stability related risks, there seems an increase in the expected returns as well. However, increases in the remaining political risk factors cause expected returns to decrease. In other words, positive developments in the political variables increases expected returns which seem to be in accordance with the reviews in previous chapters. Because a decrease in political risks represents a positive tendency in the political structure and democratization process of a country and hence has positive reflections on the economy as well.

Increase in the risks regarding internal conflict, external conflict and military in politics can be a sign of increases in political violence and threats, political pressures and limitations against the ruling government and the investments or of a dysfunction in the government system both at national and international level. Based on the findings, it can be expected capital flows to show a declining tendency toward Turkish financial markets.

Despite the fact that the relation between political risks and financial markets is not set forth explicitly in the theory, some of the previous researches state that recovery in political risks can enable a proper environment for those preferring low risk and secure investment conditions. Because decrease in the political risks increases the stability of the political environment. And therefore it is expected to lead an increase in the security of property rights, decrease in the possibility of expropriation, decrease in corruption and development of capital markets healthily.

Findings of the research show that even if one has the possibility to control the betas in explaining asset returns, investors should also consider political risks in asset valuation. In addition, these findings scientifically prove the intuitions that political risks and stock returns are related to each other. These findings are also important in terms of better understanding which political risk factors lead capital flows across countries in today's international financial markets nearly having no restriction on capital movements which also contributes to the economic welfare of a country in return.

On the other hand, this analysis can be expanded as to include extraordinary times such as the certain election or crisis periods or the analysis method can be designed to compare subsectors or include the different or new approaches such as one suggested by Maki (2012), allowing to consider structural breaks in cointegration process. Additionally, findings of this analysis also seem to be proved by the recent failed coup attempt by a junta on July 15, 2016 in Turkey which followed by a sharp decrease in the BIST100 index at the first trading day right after the failed attempt. This study is important as it emphasizes the role of the risk of military in politics in financial markets of Turkey which could not be found at the other similar studies including different countries.

\section{End Notes}

1. "This work is supported by the Scientific Research Project Fund of Cumhuriyet University as a 'dissertation project' under the project number IKT-088" and the initial version of this paper was presented at the International Congress of Management, Economy and Policy in Istanbul in 26-27 November, 2016. 


\section{References}

Abdul-Qadir, A. B., \& Yaroson, E. (2013). Does corruption matter in the development of the stock market in Nigeria?. ESUT Journal of Accountancy, 4(1), 1-20.

Ada, S. S., Bolak, M., \& Suer, O. (2013). Politik secimler, referandumlar ve hisse senedi getirileri: IMKB ornegi. Finans Politik \& Ekonomik Yorumlar Dergisi, 50(579), 23-40.

Akagun, H.Y. (2006). Finansal Varliklari Fiyatlama Modeli (FVFM) ve New York Borsasi (NYSE)'de uygulanmasi. Istanbul Universitesi Sosyal Bilimler Enstitusu, Yuksek Lisans Tezi, Istanbul.

Apak, S., \& Demirel, E. (2013). Finansal yönetim, Cilt 1: Sermaye piyasalari (2. Basim). Istanbul. Papatya Yayincilik.

Atilgan, Y., Demirtas, K.O., \& A. Erdogan (2015). Macroeconomic factors and equity returns in Borsa Istanbul. Iktisat, Isletme ve Finans, 30(349), 9-30.

Aydin, O. (2008). Portfoy yatirimlarinda yerel sapma ve Turkiye'de yerlesik yatirimcilarin bu kapsamda incelenmesi. Ankara Universitesi Sosyal Bilimler Enstitusu, Doktora Tezi, Ankara.

Bekaert, G., Harvey, C.R., Lundblad, C.T., \& Siegel, S. (2012). Political risk and international valuation, http://www.academia.edu/2686889/Political_Risk_and_International_Valuation, Accessed: 08.11.2013.

BIST (2014). Borsa Istanbul for Investors, http://www.borsaistanbul.com/data/kilavuzlar/Borsa_Istanbul_For_Investors.pdf, Accessed: 18.03.2014.

Bilson, C.M., Brailsford, T.J., \& Hooper, V.C. (2002). The explanatory power of political risk in emerging markets. International Review of Financial Analysis, 11, 1-27.

Black, F., Jensen, M.C., \& Scholes, M. (1972). The capital asset pricing model: Some empirical tests, Studies in the Theory of Capital Markets (M.C. Jensen ed.), New York: Praeger, 79-121.

Bozkurt, I. (2008). Finansal Varliklari Fiyatlandirma Modeli'nin Istanbul Menkul Kiymetler Borsasi'nda test edilmesi. Sakarya Universitesi Sosyal Bilimler Enstitusu, Yuksek Lisans Tezi, Sakarya.

Brealey, R.A., Myers, S.C., \& Marcus, A.J. (2001). Fundamentals of corporate finance (3re ed.). McGraw-Hill Primis Custom Publishing, USA.

Buyukakin, F., Bozkurt, H., \& Cengiz, V. (2009). Türkiye'de parasal aktarımın faiz kanalının Granger nedensellik ve TodaYamamota yöntemleri ile analizi. Erciyes Üniversitesi Iktisadi ve Idari Bilimler Fakültesi Dergisi, (33), 101-118.

Cam, A.V. (2014). Politik riskin firma değeri ile ilişkisi: IMKB’ye kayıtlı firmalar üzerinde bir uygulama. Doğuş Üniversitesi Dergisi, 15(1), 109-122.

Chau, F., Deesomsak, R., \& J.Wang (2014). Political uncertainty and stock market volatility in the Middle East and North African (MENA) countries. Journal of International Financial Markets, Institutions \& Money, 28, 1-19.

Comak, A. (2009). Sermaye Varliklari Fiyatlama Modeli cerçevesinde risk getiri iliskisi ve IMKB'ye bir uygulama. Marmara Universitesi Sosyal Bilimler Enstitusu, Yuksek Lisans Tezi, Istanbul.

Dimic, N., Orlov, V., \& Piljak, V. (2015). The political risk factor in emerging, frontier, and developed stock markets. Finance Research Letters, 15, 239-245.

Dutta, N. (2009). Three essays on political economy, economic development and capital flows. West Virginia University, College of Business and Economics, Dissertation, USA.

Engle, R., Jondeau, E., \& Rockinger, M. (2012). Dynamic conditional beta and systematic risk in Europe, Center for Risk Management Lausanne, http://www.crml.ch/fileadmin/contenu/fichiers/REEJMR_SystRisk-Euro.pdf, Accessed: 26.06.2014.

Eraslan, V. (2011). Testing the validity of the Capital Asset Pricing Model in Turkey. Istanbul Universitesi Sosyal Bilimler Enstitusu, Yuksek Lisans Tezi, Istanbul.

Erkocak, H., \& Cam, A.V. (2015). The role of country risk on estimating of share earnings: An application on commercial banks registered to Istanbul Stock Exchange (BIST). Journal of Business \& Economic Policy, 2(3), 92-101.

Fama, E.F., \& French, K.R. (2004). The capital asset pricing model: Theory and evidence. Journal of Economic Perspectives, 18(3), 25-46.

Fama, E.F., \& Macbeth, J.D. (1973). Risk, return and equilibrium: Empirical tests. Journal of Political Economy, 81(3), 607636.

Fama, E.F., \& Miller, M.H. (1971). The Theory of finance, Dryden Press, Hisndale, Illinois.

Ferson, W.E., \& D.H. Locke (1998). Estimating the cost of capital through time: An analysis of the sources of error. Management Science, 44(4), 485-500. 
Fitzsimons, E., \& Sun, M. (2012). An exploration of: How political risk components affect the stock return and volatility considering different countries of varying economic development, Ekonomihögskolan Lunds Universitet, http://lup.lub.lu.se/luur/download?func=downloadFile\&recordOId=2628691\&fileOId=2628692, Accessed: 29.07.2014.

Ghosh, S.(2016). Political transition and bank performance: How important was the Arab Spring?. Journal of Comparative Economics, 44, 372-382.

Girard, E., \& Omran, M. (2007). What are the risks when ınvesting in thin emerging equity markets: Evidence from the Arab world. International Financial Markets, Institutions and Money, 17, 102-123.

Grabowski, R.J. (2010). Developing the cost of equity capital: Risk-free rate and erp during periods of 'flight to quality', http://www.duffandphelps.com/sitecollectiondocuments/articles/Article_Grabowski_Risk_Free_Rate_and_ER P_During_Flight_to_Quality_01_29_11.pdf, Accessed: 27.06.2014.

Gujarati, D.N. (2004). Basic econometrics (Fourth Ed.). The McGraw-Hill, Companies, USA.

Gujarati, D.N. (2009). Temel ekonometri (Cev. Umit Senesen ve Gulay Gunluk Senesen), Literatur Yayinlari, Istanbul.

Gul, S., Khan, M.T., Saif, N., Rehman, S.U., \& Roohullah (2013). Stock market reaction to political events (evidence from Pakistan). Journal of Economics and Sustainable Development, 4(1),165-175, http://www.iiste.org/Journals/index.php/JEDS/article/view/4115/4136, Accessed: 29.07.2014.

Guris, S., Caglayan, E., \& Guris, B. (2013). Eviews ile temel ekonometri (Ikinci Basim). Der Yayinlari, Istanbul.

Harms, P. (2000). International Investment, political risk and growth. Kluwer Academic Publishers, USA.

He, H. (1999). Political Risk and stock returns: The case of Hong Kong. University of Hawai'i, Graduate Division of Economics, Dissertation, USA.

Henderson, S., \& Garza Rodriguez, I. (2008). Sensitivity of equity returns to political risk premiums, http://www.lunduniversity.lu.se/o.o.i.s?id=24965\&postid=1335021, Accessed: 08.11.2013.

Kara, E., \& L.Karabiyik (2015). The effect of country risk on stock prices: An application in Borsa Istanbul. Suleyman Demirel University The Journal of Faculty of Economics and Administrative Sciences, 20(1), 225-239.

Karan, M.B. (2013). Yatirim analizi ve portfoy yonetimi (4. Baski). Gazi Kitabevi, Ankara.

Kavurmaci, A.K. (2009). Finansal Varliklari Fiyatlama Modeli ile Arbitraj Fiyatlama Teorisinin IMKB'de karsilastirilmasi. Baskent Universitesi Sosyal Bilimler Enstitusu, Doktora Tezi, Ankara.

Kaya, A., Gungor, B., \& Ozcomak, M.S. (2014). Politik risk yatirimcinin dikkate almasi gereken bir risk midir? Borsa Istanbul ornegi,.Gazi Universitesi Iktisadi ve Idari Bilimler Fakultesi Dergisi, 16/1, 74-87.

Keles, C. (2007). Siyasi riskin finansal yansimalari uzerine bir calisma. Ankara Universitesi Sosyal Bilimler Enstitusu, Doktora Tezi, Ankara.

Kim, H.Y., \& Mei, J.P. (2001). What makes stock market jump? An analysis of political risk on Hong Kong stock returns. Journal of International Money and Finance, 20, 1003-1016.

Lehkonen, H., \& Heimonen, K. (2015). Democracy, political risks and stock market performance. Journal of International Money and Finance, 59, 77-99.

Lehmann, E.L., \& Casella, G. (1998). Theory of point estimation (2nd Ed.). Springer, USA.

Loikas, A. (2003). A government analysis of political risk: Exploring equilibrium, instability and pluralism at the local, national and supranational level in Europe. Turku School of Economics and Business Administration, Finland.

Maki, D. (2012). Tests for cointegration allowing for an unknown number of breaks. Economic Modelling, 29, 20112015.

Markowitz, H. (1952). Portfolio selection. The Journal of Finance, 7(1), 77-91.

Mei, J. (JP) (1999). Political risk, financial crisis and market volatility. NYU Working Paper No. S-MF-99-08.

Mishkin, F.S., \& Eakins, S.G. (2005). Financial markets and Institutions (Fifth Edition). Pearson Addison Wesley, USA.

Mishkin, F.S. (2007). Systemic risk and the international lender of last resort. (Eds. Douglas Evanoff, David Hoelscher and George Kaufman). Globalization and Systemic Risk, World Scientific Publishing Co. Pte. Ltd, New Jersey.

Pastor, L., \& Veronesi, P. (2010). Uncertainty about government policy and stock prices. Journal of Finance, 67(4), 12191264.

Pastor, L., \& Veronesi, P. (2012). Political uncertainty and risk premia. NBER Working Papers, No.17464, National Bureau of Economic Research, USA. 
Perotti, E.C., \& Van Oijen, P. (2001). Privatization, political risk and stock market development in emerging economies. Journal of International Money and Finance, 20, 43-69.

Ramady, M.A. (2014). Political, economic and financial country risk, analysis of the Gulf Cooperation Council. Springer International Publishing, Switzerland.

Sanlisoy, S., \& Kok, R. (2010). Politik istikrarsizlik-ekonomik buyume iliskisi: Turkiye ornegi (1987-2006). Dokuz Eylul Universitesi Iktisadi ve Idari Bilimler Fakultesi Dergisi, 25(1), 101-125.

Sengonul, A., \& Degirmen, S. (2011). Does the recent global financial crisis affect efficiency of capital markets of EU countries and Turkey?. 13th International Conference on Finance and Banking, Ostrava, Czech Republic, 12-13 October 2011, http://www.opf.slu.cz/kfi/icfb/proc2011/pdf/50_Sengonul.pdf, Accessed: 29.07.2014.

Shaffer, J.P. (1991). The Gauss-Markov theorem and random regressors. The American Statistician, 45(4), $269-273$.

Sharpe, W.F. (1964). Capital asset prices: A theory of market equilibrium under conditions of risk. The Journal of Finance, 19(3), 425-442.

Suleman, M.T. (2012). Stock market reaction to good and bad political news. Asian Journal of Finance \& Accounting, 4(1), 299-312.

Tanik, M. (2006). Finansal Varliklari Fiyatlama Modeli ve IMKB'da bir uygulama. Nigde Universitesi Sosyal Bilimler Enstitusu, Yuksek Lisans Tezi, Nigde.

Temizkaya, U.B. (2006). Finansal Varliklari Fiyatlama Modeli ve iMKB uygulamasi. Marmara Universitesi Sosyal Bilimler Enstitusu, Yuksek Lisans Tezi, Istanbul.

Toptas, M. (1996). Dogrudan yabanci yatirimlar ve analizi. Ankara Universitesi Sosyal Bilimler Enstitusu, Doktora Tezi, Ankara.

Tuncay, M. (2014). Finansal piyasalardaki sermaye varlıklarının değerlemesinde politik risklerin etkisi: Türkiye uygulaması. Cumhuriyet Üniversitesi Sosyal Bilimler Enstitüsü, Doktora Tezi, Sivas.

World Bank Group (2011). World investment and political risk. The International Bank for Reconstruction and Development, USA.

Yaprakli, S., \& Gungor, B. (2007). Ulke riskinin hisse senedi fiyatlarina etkisi: IMKB 100 endeksi üzerine bir arastirma. Ankara Universitesi Siyasal Bilgiler Fakultesi Dergisi, 62(2), 200-218.

Yartey, C.A. (2008). The determinants of stock market development in emerging economies: Is South Africa different?. IMF Working Paper, WP/08/32, https://www.imf.org/external/pubs/ft/wp/2008/wp0832.pdf, Accessed: 29.07.2014.

Yasar, S. (2010). Derin ekonomi, cumhuriyetin finansal sifreleri (4. Baski). Etkilesim Yayinlari, İstanbul. 